\title{
DEBATES
}

\section{Para bom entendedor meias palavras não bastam}

(Esclarecimento prestado face à resposta de Ciro F. S. Cardoso dada à nossa resenha do seu livro intitulado $O$ Egito Antigo, resenha esta que foi publicada no $\mathrm{n}^{\circ} 114$ da Revista de História e resposta essa que foi originalmente publicada no V. $2 \mathrm{n}^{\circ} 2$ da História em Cadernos) (1).

Francisco Murari Pires

Departamento de História - FFLCH/USP

Recomendaria Aristóteles: comecemos desde o princípio. Para o Prof. Cardoso, o que é primeiro, são "reparos" (2). Enveredemos, então, pelos "reparos" do Prof. Cardoso, pois eles nos permitem vislumbrar já aspectos dos recursos da estratégia de sua leitura da nossa resenha. Deteta, o Prof. Cardoso, dois deles, localizando-os no título: um diz respeito à correta grafia de seu nome (Flamarion, e não Flammarion), outro à correta identificação da coleção de que participa seu livrinho (Tudo é

(1) - Contra a sisudez do formalismo do sub-título entre parênteses, o título do presente esclarecimento retira sua inspiração de fontes nada acadêmicas: uma crônica de Millôr Fernandes e uma música de Chico Buarque.

(2) - Nossas aspas na resenha parece que incomodaram o Prof. Cardoso. Reclama da "abundância" das mesmas, sugerindo talvez a falta de critério de seu emprego. Neste esclarecimento, então, reservaremos esses sinaizinhos para expressões retiradas da resposta do Prof. Cardoso. 
História. e não Primeiros Passos). E termina com reticências seus "reparos" (3).

E inegável, ambos constam do título de nossa resenha. Pelo que agradecemos a amável gentileza da revisão do Prof. Cardoso. lamentando porém não retribuir-lhe revisando o seu texto à cata de tais falhas, dada a irrelevância de que se reveste essa tarefa a nossos olhos. Mas, algo nesses "reparos" nos intriga, sobretudo aquelas reticências. E perguntamo-nos: porque o Prof. Cardoso concentrou seus "reparos" exclusivamente no título? Não é que o lamentável lapso quanto à correta grafia de seu nome ocorre ainda por mais duas vezes no corpo do nosso texto (4)! Se a preocupação do Prof. Cardoso é com "reparos", porque acusá-los só no título? Entretanto, quanto ao segundo "reparo", a questão se coloca em termos totalmente outros. Pois, não só não repetimos tal equívoco (5) no restante da resenha, como ainda, pelo contrário, fizemos referência explícita à correta identificação da coleção (6). Mais ainda, no parágrafo imediatamente anterior a essa referência, nossa resenha preocupara-se em reconhecer as dificuldades enfrentadas pelo livrinho do Prof. Cardoso, ressalvando-o de suas limitações condicionantes, devidas precisamente à sua inserção em tal coleção (Tudo é História): dimensão reduzida, proposição de divulgação do saber, preocupações didáticas, intenções de afirmação interpretativa. E, face a tais limitações e à dimensão colossal do objeto recortado pelo Prof. Cardoso 13 milênios de historicidade, a serem dados conta em "60 laudas de 30 linhas"), imaginávamos o esforço hercúleo do Autor. Então, justamente porque tivemos tais cuidados com essa inserção do livrinho naquela coleção, intrigou-nos o fato do Prof. Cardoso concentrar exclusivamente seus "reparos" no título, terminados por aquelas enigmáticas reticências. $\mathrm{E}$ a questão voltava a nos martelar: se a atenção do Prof. Cardoso está preocupada com "reparos", porque situá-los só no título? Será porque, se ele considerasse também o corpo da resenha, não poderia usufruir em termos absolutos (e, portantn, não com plena eficácia) do "reparo" feito quanto à identificação da coleção (7)?

(3) - "Para começar, dois reparos ao título da resenha. Meu segundo nome escreve-se Flamarion e não "Flammarion"; e a coleção da Editora Brasiliense em que foi publicado meu pequeno livro O Egito Antigo chama-se "Tudo é His-
tória" e não "Primeiros Passos...".

(4) - Às páginas 174 e 177.

(5) - Acreditamos ser esse o lapso mais grave dos dois, sem com isto estarmos de forma alguma, tencionando ferir o orgulho do Prof. Cardoso quanto ao seu nome. Nenhum dos dois lapsos constava do nosso original datilografado. Todavia, ambos passaram por nossa descuidada revisão.

(6) - No penúltimo parágrafo da p. 174 .

(7) - Voltamos a insistir, trata-se do equívoco mais grave, 
Será que o Prof. Cardoso está querendo, com tais "reparos" assim localizados, insinuar algo além do mérito dos mesmos em si? $\mathrm{E}$ lá, na resposta do Prof. Cardoso, estavam aquelas terríveis reticências como uma sutil pista para bons leitores, o que, supõe-se, todo historiador deva ser. Mas, nesse caso, Prof. Cardoso, não constituiria procedimento de melhor lisura ter feito reparos aos seus próprios "reparos", reparando, por sua vez, que havíamos corretamente reparado o nome da coleção? Sobretudo considerando-se a forte possibilidade do leitor de sua resposta ser iludido por não ter tido acesso à minha resenha, já que essa resposta foi originalmente elaborada para ser divulgada em outro periódico que não a Revista de História (8). Pois, Prof. Cardoso, a gravidade dos vossos "reparos" está não neles mesmos, como se por eles se estivesse fazendo uma mera constatação de passagem no exercício da crítica, mas nas reticências que insinuam algum outro tipo de "erro" subsumido no "reparo" denunciado.

E assim, vislumbramos já a face da estratégia de leitura do Prof. Cardoso. Ela destaca algum "erro" na forma de uma denúncia, projetando suas luzes em alguma passagem de nossa resenha. Mas, para tanto, ela apaga, ela lança trevas, ela esquece outras cuja lembrança diluiria a eficácia de suas luzes acusatórias.

E Aristóteles tinha razão. Pois que o exame do princípio é fundamental para revelar a identidade daquilo de que ele é o início da constituição. Se não, vejamos a estratégia global de leitura do Prof. Cardoso que se segue àquele começo, constituindo a sua resposta. Nela fui generosamente agraciado com um detalhado bombardeio à minha resenha. Lá estão profusamente distribuidas magnânimas denúncias de "erros", "equívocos", "deslizes", "desinformações", "desatualizações", "inverdades", etc. Mas, pergunto-me, como desencavou o Prof. Cardoso tais denúncias? Permita-me, então, Prof. Cardoso, parafrasear uma de suas acusações, apontando, de meu lado, a estratégia geral de vossa resposta que possibilita tal dilúvio acusatório. "Comete o Prof. Cardoso um deslize muito comum em respostas do tipo da sua": o de operar a leitura do texto pela fragmentação do discurso. Ao atomizar a resenha, segmentando-a em passagens tornadas autônomas e absolutas por essa operação de recorte mutilador, não apenas (des)apreende ou oblitera o sentido e o alcance das mesmas, como ainda elide pelo esquecimento a reflexão global da resenha, construída pelo desenvolvimento e articulação das idéias elaboradas

(8) - História em Cadernos, v. 2, no 2, set.-dez. 1984, pp. 42-45, editada pelo Mestrado em História do IFCS da UFRJ, Rio de Janeiro, sob o título de: Resposta à resenha crítica de autoria de Francisco Murari Pires acerca de $O$ Egito Antigo, de Ciro F. S. Cardoso, publicada no $n^{o} 114$ da Revista de História (Säo Paulo, USP), Nova Série, 1983, pp. 173-177. 
nas passagens parciais. Por essa operação de recorte, mata-se o discurso para dissecar seus pedaços. Trata-se de uma leitura patológica do discurso: atua munida de tesoura, bisturí e pinça. Então, desentendendo, ou entendendo mal (9), o sentido e o alcance das passagens, o Prof. Cardoso põe em movimento os tanques de sua estratégia denunciadora: marca gentilmente a ignorância (10) de nossa resenha e, a partir daí, dá vazão à sua vocação professoral, ministrando doutas aulas para extirpar a ignorância por ele captada. $\mathrm{Na}$ realidade, extirpa o mal entendido, ou o desentendido construído pela sua leitura patológica (11).

O primeiro movimento da estratégia de leitura compõe-se, portanto, dessa associação entre a operação de recorte fragmentador do discurso e o enfoque seletivo-obliterador. É tal associação estratégica que permite construir o télos que comanda a constituição efetivadora da sua phýsis fundadora: a denúncia da ignorância. E este télos abre o caminho para o segundo movimento: deslocar a reflexão sobre o livrinho do Prof. Cardoso do campo por mim proposto na resenha - essencialmente epistemológico - para outro que talvez goze da melhor predileção do Autor o domínio dos conteúdos de saber constituídos e instituídos. Quer dizer: primeiro, o Prof. Cardoso cria, pela sua leitura, a fantasmagoria da ignorância; depois, exibe o seu saber como forma de sua reação ao fantasma. E essa exibição de domínio de conteúdos de saber se efetua subordinada ao enfoque tópico: circunscreve as questões pelos topói produzidos pelos recortes. Vejamos este segundo movimento com mais vagar.

A leitura de nossa resenha pelo Prof. Cardoso supõe que esta devesse ter sido comandada por uma hýbris megalomaníaca, dado que a sua cobrança está negativamente implicada em sua resposta (a ausência de saber, ou ignorância, que produz a aparição do fantasma). A resenha, Prof. Cardoso, não é nem desempenho nem exibição quer de erudição, quer de domínio e atualização bibliográfica, quer de posse e controle

(9) - Entre essas duas possibilidades - desentender ou entender mal não podemos decidir qual delas foi efetivamente realizada pela leitura do Prof. Cardoso. Trata-se de uma questão que resvala pelas intenções do Autor do texto. $\mathrm{E}$ estas perdem-se na contra-face de trevas que produzem o texto, mas não transparecem nele (não temos certeza se esta idéia nos veio de alguma leitura de Merleau-Ponty, talvez dos Signes). Certamente o Prof. Cardoso pode dirimir tal dúvida, e assim devidamente decidir qual o significado que bom possui no título de nosso esclarecimento.

(10) - Ignorância vai a partir daquí sem aspas, não porque a estejamos auto-reconhecendo, mas porque fizemos o propósito de reservar esses impertinentes sinaizinhos para expressões explicitamente empregues pelo Prof. Cardoso em sua resposta.

(1і) - Bons exemplos dessa estratégia encontram-se no primeiro parágrafo da p. 42 referindo-se à tradição marxista e à elaboração do "modelo" do Modo de Produção Asiático, ou no primeiro da p. 44 referindo-se à Idade do Bronze no Egito, ou no último da p. 44 referindo-se à questão da "nação-Egito Antigo". 
da documentação empírica, seja referindo-se ao objeto $O$ Egito Antigo, sejá referindo-se aos temas da tradição marxista (mais especificamente, Modo de Produção Asiático). Consequentemente, ela não foi elaborada por meio de compulsão bibliográfica e composição de conteúdos de saber constituidos, como se ela tivesse por propósito duelar contra os conteúdos de saber afirmados pelo livrinho (12). Quer dizer, a resenha não se preocupou em professoralmente ministrar aulas, despejando informações e interpretações, e ainda privilegiando-as e santificando-as por auréolas de "recentes". E ela não é toda essa hýbris megalomaníaca por algumas razões. E que, para sê-lo, supor-se-ia ter cuidado do acesso aos recursos materiais facilitadores daqueles desempenhos e exibições (13). $E$ a resenha não têm esse cuidado porque não elege como valor da sua reflexão o escudar-se em notas de rodapé bibliográficas: ela não está preocupada em inflar-se pela segurança do saber instituido. Mesmo porque tal segurança propiciada pelo acúmulo de informações como valor imanente. corre um risco já apontado por Nietzche há cerca de um século atrás quando teve o dissabor de com ele defrontar-se: “... igual à cobra que engoliu coelhos inteiros e em seguida, quieta e serena, se deita ao sol e evita todos os movimentos, além dos mais necessários. $\mathrm{O}$ processo interno: tal é agora a coisa mesma, tal é propriamente a cultura. Todo aquele que passa por ali têm um único desejo - que uma tal cultura não morra de indigestão" (14). E a resenha não cultua essa exibição de informações ancoradas em conteúdos de saber constituídos, porque não privilegia como seu télos o exercício da autoridade do saber como discurso competente (15). Assim, a resenha não está tomada pelo espirito da sagrada cientificidade que percorre superiormente o mundo intelectual como um anjo exterminador: munido da espada da "verdade" do saber instituido, purifica-o maniqueisticamente apontando "deslizes", denunciando "erros", revelando "desinformaçōes", acusando "equívocos". Em suma, arvorando-se em autoridade do saber aureolada de cientificidade, tal exercício do discurso competente vai distinguindo quem deve falar, e quem calar, quem deve ensinar, e quem aprender, quem deve mandar, e quem obedecer.

(12) - Quanto à referência que fizemos acerca da proposta interpretativa do curso de pós-graduação mencionado na resenhą, e que o Prof. Cardoso toma por contraposição de saber constituido, taxando-a de a minha "verdade", esclareceremos mais adiante o sentido estratégico da mesma na construção da reflexão de nossa resenha.

(13) - Mormente no que diz respeito ao objeto referido (o Egito Antigo).

(14) - Nietzche, F., Da Utilidade e Desvantagem da História para a Vida. In Obras Incompletas. Tradução de Rubens R. Torres Filho, São Paulo, Abril Cultural, 1974, p. 70 .

(15) - Confira-se este último conceito no belo texto de Marilena Chauí. O Discurso Competente, In Cultura e Democracia, São Paulo, Moderna, 1980, pp. 3-13. 
Então, Prof. Cardoso, a resenha não é um catálogo de conteúdos de saber justapostos, apresentados à guisa de desafio aos vossos enquanto confronto de autoridade, como quereis entender. Não é esse - o ciomínio do saber instituido - o campo em que a resenha se situa. Nàc. ela visa a uma reflexão epistemológica. Ela focaliza sua atenção nas categorias e operações que fundam o discurso formulador de saber con:tituinte do livrinho. Por isso, o plano em que ela se situa é o do sentidor global do livrinho, e não o dos tópoi restritos. Também porque, se a restnha pretendesse ser esse duelo alimentado por aquela erudição, serıe a prova mais cabal da sua burrice o ser resenha. Nesse caso. mais intel:gente seria ser artigo, e mais esperto, ser livrinho. Quer dizer, uma tal resenha ao vosso livrinho seria, parafraseando vossos próprios dizeres, "honrá-lo" demasiadamente, o que aliás, não seria "nem sensato nem pertinente". Assim, ela é meramente uma resenha. Não têm a pretensão de ser mais do que isso. Porém, também, não menos. Ou seja, ela se posiciona como crítica, pois encara o livrinho como produto intelectual, construindo sobre ele uma reflexão. Talvez esse seja seu grande equívoco. Realmente, ela poderia visualizar o livrinho como mercadoria, já que o é. Reclamar-se-ia, então, uma boa propaganda, pois, por esse viés, ele não se diferencia essencialmente de um sabonete numa prateleira de supermercado. Ou ela poderia enxergá-lo como expressão de autoridade, o que o livrinho pode almejar ser. Reclamar-se-ia, então, reverência, se não mesmo louvação. Se tais forem os horizontes que se descortinam para a resenha do livrinho, certamente não somos nós a fazê-la.

Vejamos, agora, o que a resenha é enquanto tal: qual é a reflexão que ela constrói ao tecer suas idéias, o que a leitura fragmentadora do Prof. Cardoso perdeu.

Ela começa situando o horizonte de proposições onde pretendemos enfocar o livrinho do Prof. Cardoso. O polo central desse horizonte $́$ a preocupação teorizante e conceitual, enquanto postulação de contraposição e superação da vertente histórica empirista. Um dos recursos pelos quais opera essa preocupação é o de apresentar-se por uma identidade que reclama ser marxista. Uma das roupagens conceituais efetuadoras de tal reivindicação é, particularmente quando se analisa o objeto em questão, o de Modo de Produção Asiático. Já desde o início, portanto, os elementos chaves de nossa leitura do livrinho estão colocados: pela postulação marxista, afirmar-se como superação do empirismo positivista.

O Prof. Cardoso, em sua resposta, opera já aqui um de seus recortes de proposição acusatória. Primeiro, aponta o nosso "deslize": "Comete, então, um deslize muito comum em ataques do tipo do seu: o de construir um objeto que ele chama de "marxismo" mas que, quando muito, terá algo em comum com os manuais dogmáticos soviéticos, estalinistas ou 
pós-estalinistas" (16). Bem, a nossa referência ao marxismo foi efetivamente vaga e abrangente. Agora, a sua identificação redutora pelo "dogmatismo soviético" fica por conta dos zelos do Prof. Cardoso com ○ marxismo. Gostaríamos de esclarecer não estarmos preocupados com tal identificação, em qualquer sentido que seja (positivo ou negativo). Realmente, o tópico temático marxista que diz respeito ao livrinho do Prof. Cardoso é o Modo de Produção Asiático. Mas, por outro lado, aquele zelo do Prof. Cardoso revela um aspecto da sua preocupação marxista que nos parece relevante em termos da reflexão global construída em nossa resenha. Com aquela ressalva, o Prof. Cardoso está evidentemente desejando beneficiar o marxismo por meio da eficácia catártica de tal ressalva (purifica meramente pela manifestação de horror). Pois, o que está o Prof. Cardoso a expurgar com tal ressalva: do marxismo o "dogmatismo soviético", ou, pelo contrário, do "dogmatismo soviético" o marxismo? A quem busca ele salvar? Sem dúvida, a proposição é a primeira por nós apontada. Entretanto, acontece que ela implica a segunda (17). Claramente, pois, a apresentação marxista do Prof. Cardoso recende a aromas apurados porque depurados.

E seguindo imediatamente aquela ressalva, o Prof. Cardoso aciona a sua acusação denunciatória de ignorância: "Quantos autores marxistas conhece o Prof. Pires que estejam preocupados, hoje em dia, com a identificação e o enquadramento das sociedaeds, numa sucessão unilinear dos modos de produção?" (18). E daí vem a aula. Parece que o Prof. Cardoso entendeu que o nosso propósito na resenha era o de situar o seu livrinho nesse horizonte impuro e espúrio. Esse entendimento pode ser construido pela leitura de nossa resenha: basta iluminar a segunda parte du primeiro parágrafo da mesma $e$ deixar nas trevas o esquecimento da primeira parte (a postulação teorizante-conceitual através da apresentação marxista). E esse esquecimento é definitivo: comanda o restante da leitura do Prof. Cardoso.

Mas, é essa apresentação marxista o alvo do nosso propósito, e não aquele horizonte impuro e espúrio. O exame do objeto da denúncia acima - quantos autores marxistas conhece o Prof. Pires - permitenos esclarecer melhor este ponto. A denúncia reclama duas coisas imbricadas: o conhecimento da identidade marxista, e o seu reconhecimento quantitativo. E da forma como o Prof. Cardoso a coloca, ele sugere que se trata de questões razoavelmente simples. Sem dúvida, se o proce-

(16) - $\AA$ página 42, segundo parágrafo.

(17) - De qualquer forma, eis um vespeiro em que não colocaremos a mão, competindo antes ao Prof. Cardoso (des)entender-se com a diplomacia soviética, ou com seus avatares burocráticos (partidários, acadêmicos, etc.).

(18) - No mesmo segundo parágrafo da página 42. 
dimento de resolução das mesmas consistir em reconhecer essa identidade através da auto-apresentação da mesma nos diversos autores (expurgados já os de berço "estalinista ou pós-estalinista"), a questão consiste em ler e contar. Mas, e se tal reconhecimento for algo mais problemático e delicado? Vêmnos à memória pelo menos dois autores que já se colocaram essa questão, aos quais devemos reconhecer a inspiração da nossa reflexão na resenha, no que diz respeito a esse ponto. Um deles é Pierre Vilar, o qual começa precisamente o seu conhecido texto polêmico com Althusser apontando que se há algo "mais raro $e$ dificil do que ser historiador é ser historiador marxista" (19). E ensejara-lhe tal comentário uma constatação sobre a fácil mercantilização da história: "O comércio da história tem isto em comum com o comércio de detergentes: é que nele faz-se de bom grado passar a novidade pela inovação". O outro autor é Gerard Lebrun. Com a sua refinada ironia, ele ilumina questões fundamentais para a nossa reflexão. Em uma delas, aponta para a dissociação ação/pensamento: "... pois inumeráveis são os "liberais" que se ignoram como tal: conheço muita gente, no Brasil e fora dele, que pensa conforme Marx e vive segundo Guizot" (20). Em outra delas, essa camuflagem do liberal no marxista retorna, apontando agora a dissociação - orientação manifestamente reivindicada/horizonte fundador: "Se, espontaneamente o leitor assim pensa a coisa política, não tenha dúvidas: ele é liberal... sem o saber. E melhor que feche Marx, Lênin e Trotsky - e vá logo consultar Benjamin Constant e Herbert Spencer, os seus verdadeiros pais espirituais" (21). É sobretudo este último o ponto em que queremos tocar pela reflexão tecida na resenha: a reivindicação de orientação marxista do livrinho é construída sobre o alicerce da fundação positivista que ele afirma estar superando por meio dessa reivindicação (22).

Tal reivindicação marxista como contraposição teórico-conceitual ao positivismo empirista foi, a seguir na nossa resenha, referida especificamente a três aspectos do livrinho. A proposição marcadamente (23) des-

(19) - Vilar, P., Histoire Marxiste, Histoire en Construction, In Le Goff, J. e Nora, P., Faire de l'Histoire, Paris, Gallimard, 1974, pp. 169 (grifos nossos).

(20) - Lebrun, G., Passeios ao Léu. São Paulo, Brasiliense, 1983 p. 53.

(21) - Lebrun, G., $O$ que é Poder. São Paulo, Brasiliense, 1981, p. 83. Em ambas as passagens, o contexto temático que suscita o comentário de $G$. Lebrun diz respeito à dissociação operada pelo pensamento liberal entre socialindivíduo-liberdade e político-estado-poder.

(22) - Positivista está sendo aqui empregue por nós mais como categoria classificatória (como, por exemplo, o referir-se ao manual positivista de Langlois-Seignobos), que possui uma carga semântica firmada por uma tradição, do que propriamente como conceito precisamente delineado no seu conteúdo (o positivismo comteano).

(23) - Em nossa resenha, havíamos observado que nos três capítulos centrais do livrinho do Prof. Cardoso, o discurso do Autor assume marcadamente uma proposição descritiva. Em sua resposta, o Prof. Cardoso revela não ter ficado 
critivo-informativa por ele assumida mormente nos três capítulos centrais, proposição essa que pretendemos articular com o sentido geral do livrinho (24); a afirmação do Prof. Cardoso de que, pelo livrinho, não mais se teria, como nos velhos manuais positivistas, o império do político na sua forma tradicional de peripécias dinásticas; e o envoltório teóricoconceitual propiciado pelo Modo de Produção Asiático. E a interrogação por nós levantada, era a de se efetivamente o livrinho estava marcando mesmo a superação dos manuais positivistas que ele reclamava? Constituia mesmo uma inovação? Pois, à medida em que líamos o livrinho. ficava-nos a clara impressão de que toda aquela divulgação de informações, nuançadas por momentos de discussão interpretativa (como quer $\circ$ Prof. Cardoso em sua resposta), estava, essencialmente e no plano global do livrinho, respondendo pela velha mania positivista de, à guisa de divulgá-las, catalogá-las em manuais (25)! E isso, afirmando expressamente estar superando-os. Mas, a passagem do político-exclusive para o político-inclusive efetivamente supera a categoria fundante daqueles manuais - o fato histórico - . base constitutiva do catálogo de informações que eles elaboram? Igualmente, a operação metodológica que os constitui - a fragmentação atomizadora — fica superada por essa proliferação diversificada de unidades informativas (políticas, econômicas, sociais, culturais, religiosas, etc.)? Ou, e apesar de sua declaração em contrário, 0 livrinho efetivamente reproduz e consagra tais categorias e operações me-

lá muito contente nem com o marcadamente nem com o descritivo. Desloca este último termo por "informação atualizada", e aquele primeiro por "predominantemente": "Sem dúvida, predominaram intenções de proporcionar informações atualizadas" (à p. 43, grifos nossos). E daí, já afirmando que eu tinha dito na minha resenha que aqueles capítulos do seu livrinho eram "pura descrição", passa a arrolar as passagens do mesmo onde primam "explicações" e não propriamente "descrições". Temos aqui uma nova faceta da estratégia de leitura do Prof. Cardoso: opera por meio de curiosos deslocamentos semânticos como recurso de criar o fantasma a ser combatido. Pois, o que eu observei com aquela frase da minha resenha, o Prof. Cardoso reconhece em sua resposta em outros termos. Agora, se a nossa observação foi por demais contundente, como parece se ressentir a resposta do Prof. Cardoso, então pode-se atenuá-la consultando devidamente os reparos que the dedicou o Prof. Cardoso em sua resposta: lá acham-se cuidadosamente indicadas as passagens do seu livrinho onde encontrar tais lenitivos balsâmicos.

(24) - Este ponto merece destaque. Enquanto nós nos preocupamos com a leitura do livrinho do Prof. Cardoso no plano mais geral da sua totalidade, ele enxerga-o topicamente: aqui, nesta passagem, foi dito isto, ali, naquela passagem, foi dito aquilo, etc. Quer dizer, no plano geral do livrinho, está ele construido mesmo pela justaposição de entidades informativas dissociadas (a economia, a sociedade, o poder, a cultura) como recomenda a lição dos tradicionais 'manuais positivistas.

(25) - Gostaríamos de deixar claro não estarmos aqui pretendendo compor uma catilinária contra os manuais positivistas. A nossa questão está voltada contra aquela pretensão de afirmar-se como superação dos mesmos, quando, na prática efetivada, os reproduz. 
todologicas? Em outros termos, o livrinho inova ou conserva? E ele uma reação ou afirmação dos manuais positivistas?

E essa questão da criatividade $e$ inovação da proposta de constituição de um saber, pois é delas que estamos tratando, imbricava-se com a interrogação sobre a afirmação que marca o télos de inteligibilidade do livrinho: "o modelo do Modo de Produção Asiático como o que melhor explica o caso da formação social egípcia". Pois, se essa inteligibilidade está essencialmente dada de início pelo modelo, e a tarefa que cumpre ao historiador é a de efetuar o seu teste/aprimoramento através do empírico, teceremos algumas considerações. De um lado, reafirmar o parecer emitido já em nossa resenha: exaltar a criatividade dos teóricos que geraram o modelo (26). Mas, por outro lado, lamentar a desobrigação de criatividade interpretativa dos historiadores checadores de modelos. Parece-me ser esse um télos redutor e empobrecedor para o trabalho de historiar, apesar mesmo de, com ele, o historiador munir-se, de um lado, da autoridade do estatuto de cientificidade e, de outro, do prestígio político da identidade marxista quando o modelo permite tal identificação (27). A criatividade é uma virtude rara na sociedade de massas. Desobrigarse dela no mundo intelectual, sacrificando-a pela cientificidade (privilegiada na forma de teste de modelos) e terminando por acrescentar um ou outro tijolo nesse edifício interpretativo já construído, torna a prática do historiador algo menor. Pois, muitos checam teorias e modelos, muitos também as reproduzem compondo-as, mas muito poucos efetivamente as criam. E, alerta a história da visita de Einstein ao Brasil, é na criatividade que deve residir 0 espírito de cientificidade: singelamente comentou ele ter tido somente uma idéia na vida, daí sua despreocupação em portar caderninhos que as registrassem assim que elas aflorassem na sua multiplicidade.

F. chegamos ao ponto central da resenha e da reflexão por ela construída: a questão da incidência da categoria nação, enquanto entidade individualizada e separada por uma operação de recorte, no tratamento interpretativo do objeto (O Egito Antigo). E aqui devemos reconhecer

(26) - Seja Marx, sejam os demais que efetivamente contribuiram.

(27) - Tanto pela leitura do livrinho, quanto pela da resposta, temos a impressão de estar o Prof. Cardoso conduzindo a cientificidade da sua prática de historiador segundo os preceitos da metodologia hipotética-dedutiva de inspiração popperiano-hempeliana. Especialmente quando ele atribui ao empírico esse télos de checar modelos. Referindo essa questão, entretanto, ao âmbito da criatividade, parece que a inspiração do Prof. Cardoso deixa de ser tanto popperiana, lembrando antes a burocrático-kuhniana. Tais impressões são reforçadas pela presença em seu discurso de categorias privilegiadas pela epistemologia/filosofia da ciência muito em voga entre os teóricos americanos, especialmente preocupados em reconhecer o estatuto de cientificidade no discurso historiográfico (teoria, explicação, descrição, modelo, teste da teoria, etc.). Suponho que todas essas questóes são convenientemente harmonizadas por ele com a dialética marxista. 
que a idéia por nós elaborada, lá na resenha, não se realizou plenamente. Ela ficou presa, entravada, acarretando uma redução no alcance da crítica que tencionávamos dirigir ao livrinho. Precisamente, a questão foi entravada no seu desenvolvimento pelo fato de nossa atenção ter ficado centrada no tema da periodização do objeto, segundo o tradicional e cristalizado esquema de segmentação da história egípcia em reinos, alternados por períodos intermediários. E isso porque, por essa temática, retornava com toda força no livrinho a dualidade instigadora da nossa leitura: pretensão inovadora de superação do velho/prática conservadora-reprodutora do velho. E a questão fundamental - a categoria nação suposta pelo objeto (28) - ficou relegada a segundo plano, apesar de estarmos plenamente conscientes de ser ela que fundava e presidia aquele esquema, bem como lhe inoculava sentido. Daí a redução do alcance da crítica, pois não aprofundamos o vislumbre de que as determinações implicadas pela categoria nação atingem bem mais longe: presidem e fundam, bem como dão sentido, ao livrinho na sua totalidade e enquanto tal.

E foi exatamente neste ponto que fizemos referência à proposta interpretativa do curso de pós-graduação mencionado na resenha. Há aqui

(28) - O Prof. Cardoso declara ter-lhe ficado obscuro o meu uso da expressão a suposta nação egípcia. Aventa a hipótese de que, com tal expressão, estávamos querendo afirmar 'a inaplicabilidade do conceito de nação às sociedades antigas". E daí, desenvolve sua argumentação no sentido de provar que o termo e "perfeitamente aplicável": "...acrdeito que no caso do antigo Egito tenhamos uma nação - não suposta e sim bem real". Esclarece também o Prof. Cardoso que lá no livrinho "referira-se à nação como termo algo anacrônico", não porque precisamente o fosse, mas porque estava ele preocupado em, mais uma vez, não "desconcertar" a cabeça dos pobres leitores ("condicionada a associar em forma automática tal significante somente a um de seus significados possíveis: o que remete ao referente constituido pelas formas modernas e contemporâneas do fenômeno nacional"). E sempre a mesma estratégia que constrói a leitura do Prof. Cardoso: desentendimento, aparição do fantasma para esclarecer tal obscurecimenta, demonstração de saber para exorcizar o fantasma. Se bem que, neste caso, até que o saber não é lá tão impressionante, pois, a etimologia de nação pode ser resolvida pela simples consulta a um bom dicionário de latim, e a exibição dos conceitos linguísticos ("significante/significado", como a dupla face constituinte do signo) também não requer lá grande domínio seja do saber linguístico seja semiótico (ainda se o Prof. Cardoso estivesse demonstrando conhecer os conceitos de sema e semena, ou de forma e substância, ou de desempenho e competência, ou de sistema, norma e fala, e assim estivesse referindo leituras não só de Saussure, mas também de Chomsky, Hjelmslev, Pottier, Coseriu, e outros, então ficaríamos bem melhor impressionados). Por outro lado, é pena que os egípcios do III milênio $\mathrm{aC}$. não soubessem latim, pois que então poderiam ter propiciado, com a historicidade apropriada, ainda maior concretude e "realidade" à nação egípcia do Prof. Cardoso. Dois pontos, entretanto, temos ainda que esclarecer. Efetivamente não acreditamos que o conceito moderno de nação possa ser aplicado ao "Egito Antigo". Mas, não era essa a questão que estávamos interessados em ressaltar com aquele nosso emprego da expressão - a suposta nação egípcia. E sim: a nação implicada no objeto Egito Antigo, pois que este a admite enquanto entidade separada por uma operação de recorte. 
um mal entendido pela leitura do Prof. Cardoso. Quis ele entender que, com tal referência, instauramos aquela proposta interpretativa como a nossa "verdade". Quer ainda entender o Prof. Cardoso que "endossamos" tal proposta a fim de contrapor esse "saber-verdade" ao por ele exarado em seu livrinho. A partir desse mal entendimento, entra novamente em operação a sequência da estratégia de leitura do Prof. Cardoso. Arma-se ele com os mais "recentes" escudos bibliográficos para, muito modesta e singelamente, revelar que, pelo contrário, é ele quem está iluminado pela "verdade" do saber em questão.

Esclarecemos que nossa relação com aquela interpretação não é regulada por esse tipo de utilização que o mal entendimento do Prof. Cardoso sugere. Seria muita petulância da nossa parte arrogarmo-nos a autoridade de "endossar" o conteúdo de saber daquela proposta interpretativa como "verdade" (29). Sobretudo porque ela de forma alguma carece de tais práticas fiduciárias, como se estivesse querendo assegurar seu valor no mercado do saber. Também, não tem aquela referência o propósito de contrapor saberes constituidos medindo-os pela "verdade" científica, por não sei qual padrão de medida (o do Prof. Cardoso parece privilegiar o "recente"). Por serem essas as formas do Prof. Cardoso relacionar-se com o saber, não há porque supor sejam elas igualmente as minhas. Não, a referência à proposta interpretativa do curso não contrapõe "verdades" postuladas para serem "endossadas". O que ela busca naquele curso de pós-graduação não é a arma do saber constituído, mas sim a idéia enriquecedora em que esse saber está constituído (30). Idéia que nos vale na resenha enquanto instância de argumentação, não contra as notas de rodapé bibliográficas que o Prof. Cardoso acumula em sua resposta, mas contra a sua forma de pensar e produzir um discurso interpretativo. Vejamos este ponto com mais vagar.

A idéia por nós visualizada naquele curso foi essencialmente a de constituir o seu objeto de análise por uma ótica que não a circunscrita pela categoria nação. A largueza e amplitude dos horizontes descortinados por essa ótica, ao superar a miopia do enfoque tradicional da Antiguidade

(29) - Esclarecemos que, pelo fato de não estarmos "endossando verdades". isso não implica que não estamos mais acolhendo a proposta interpretativa dó curso. Esclarecemos, pois, que o caráter "recente" da bibliografia, ou mesmo o acúmulo de exemplares desta, por si e enquanto tais, não compõem os nossos critérios para acolher conteúdos de saber. O nosso acolhimento daquela proposta destaca a riqueza da ótica que produz tal interpretação, não como "verdade" (e, portanto, como saber terminado, fechado), mas como proposta em aberto, a qual marca a efetivação do novo como iniciativa criadora (para referi-lo em termos caros a Hannah Arendt).

(30) - Como já observamos anteriormente o campo em que se situa a nossa resenha é, não o domínio do saber constituído e instituído, mas sim, primordialmente, o da reflexão epistemológica. 
como mosaico de nações recortadas e separadas, enriquece a interpretação: ao invés de enquadrar a historicidade da trajetória do estado faraônico naquele esquema periodizante como sua instância de inteligibilidade a priori, explica e interpreta os tópicos supostos por este esquema a partir da historicidade da trajetória de organização das relações de troca promovidas por aquele polo estatal nos horizontes amplos do tráfico de longa distância.

E o alcance da crítica, lá na resenha, parou aí. Ela ficou marcando ○ tema da periodização, abandonando então a questão fundamental: a da nação, à qual a da periodização está subordinada. Avancemos, pois, a crítica. Esqueçamos, então, de vez, as categorias do discurso metodológico do Prof. Cardoso, com as quais, lá na resenha, apontamos a sua contradição e incoerência: entre o preceito daquele seu manual de metodologia (31) e a negação do mesmo na prática efetivada do livrinho-manual. Estamos nos referindo às categorias de interior/exterior. É evidente. elas só adquirem sentido pela ótica da nação diferenciada e separada por recorte. Que elas permaneçam lá no manual do Prof. Cardoso, e percamos assim a nossa ingenuidade: ficar preso aos horizontes metndológicos do manual, acarreta cegueira quanto à eficácia própria dos mesmos, qual seja, a de desorientar metodologicamente pela fixação de "princípios", normas, preceitos, orientação e valores.

(31) - Trata-se do manual alentado, em co-autoria com H. P. Brignoli. Em sua resposta, o Prof. Cardoso busca desfazer-se da contradição por nós apontada, por meio de uma estratégia de argumentação que compõe duas afirmações básicas, as quais abrem e encerram essa reflexão. Primeiro, procura ele subsumir as "variáveis externas" na categoria do "interno" à "nação". E, no fim, declara ser sua "opinião que a queda do Reino Antigo ligou-se, em última análise, a contradições internas" (e firma esta "opinião" numa sua leitura do "texto contido no recto do Papiro Leiden $\mathrm{n}^{\circ} 344^{\prime}$, a qual deve constituir uma das preciosidades que o Prof. Cardoso reserva para outros leitores e públicos). Ora, mas lá, no manual de metodologia, "os contatos, ou a circulação cultural" eram "variáveis externas". Aqui, no livrinho, no caso do Egito Antigo, viraram "internas". Mistério próprio da terra dos faraós. Lá, no manual de metodologia, o considerar "as variáveis externas" era "princípio" que atuava como arma de denúncia, da parte do Prof. Cardoso, contra as limitações de vertentes da tradição marxista. Aquil, no livrinho, a questão ficou reduzida a firmar "opinião". Ora, então. também aquelas vertentes têm o direito de firmar as suas opiniōes, e não há por que cominá-las com tal princípio. A estratégia seguida pelo Prof. Cardoso no propósito de dissolver a contradição por nós apontada, trouxe-nos à lembrança um truque que lemos, há iá algum tempo, no José Bálsamo de Alexandre Dumas (1a parte das Memórias de um Médico). Voltada a arma contra a cabeça do herói, ao se dispará-la, movia-se pelo gatilho uma mola que fazia a pólvora e a bala cairem na coronha. De forma que a arma só serve para aterrorizar aqueles que não conhecem o truque. Mas ao encanto de Alexandre Dumas, nós tudo permitimos. Até mesmo o fazer conviver no romance uma nostalgia pelos nobres valores da aristocracia do Antıgo Regime com um charlatanismo revestido de heroismo e idealismo revolucionários. Pois, não nos esqueçamos, José Bálsamo é Cagliostro. Agora, no discurso da cientificidade... (nossa vez das reticências, Prof. Cardoso). 
E que a categoria nação domina e comanda o pensamento do Prof. Cardoso pode ainda ser comprovado na passagem inicial que abre o seu tratamento da questão a que nos referimos acima: "Convém salientar, antes de mais nada que o Egito do III milênio aC., e mesmo de boa parte da primeira metade do milênio seguinte, ao contrário da Baixa Mesopotâmia, não pode ser caracterizado como integrando a Idade do Bronze, já que sua tecnologia limitava-se então ao cobre, predominando aliás no instrumental os elementos líticos e de madeira" (32). Trata-se de. uma passagem que, embora rápida e curta, nem por isso deixa de ser altamente reveladora. Ela, por um lado, tece o efeito próprio da estratégia de leitura por nós indicada: num tom de despretensão ("Convém salientar...") destila o veneno da denúncia de ignorância. Mas, ela revela ainda mais: exemplifica a intensidade do comando da categoria nação na operação de pensar do Prof. Cardoso. Vamos nos deter um pouco mais aqui.

A argumentação do Prof. Cardoso é a de que nós integramos indevidamente o Egito do "III milênio aC., e mesmo de boa parte da primeira metade do milênio seguinte" na Idade do Bronze por ignorarmos a informação que ele faz questão de "salientar". Mas, será mesmo que nós a ignoramos ao nos referirmos à Idade do Bronze? Será que a desconhecíamos por "desatualização", como usualmente o Prof. Cardoso compraz-se em denunciar? Será que o Prof. Cardoso retirou-a dos recônditos bolsinhos da mais "recente" bibliografia de sua biblioteca? Até que, no caso, não é tanto, pois ele cita um livro de 1971 nas suas pródigas notas de rodapé, e mesmo assim, trata-se de uma segunda edição. E não é que o conteúdo essencial dessa informação já era conhecido por Leonard Wooley pelas décadas de 1960/50, ou por Gordon Childe nas de 1940/30? $\bigcirc$ que, então, agrava a denúncia de ignorância. Mas, será mesmo que pela nossa utilização da categoria Idade do Bronze estávamos ignorando tal conteúdo de informação? Quer dizer, ao referirmo-nos à Idade do Bron$z e$ estávamos afirmando, como "salienta" o Prof. Cardoso, que lá na terra dos faraós a tecnologia "predominante" era a do metal de bronze? Ou pode ser que Idade do Bronze comporte também valores semânticos que não exclusivamente o apontado e suposto pelo Prof. Cardoso? Mesmo numa primeira abordagem da expressão, a do leigo no assunto em questão mas que tem consciência do fato da polissemia, talvez isso já possa ser desconfiado. Pois, a expressão compõe-se de dois vocábulos: bronze, onde se detém a atenção semântica do Prof. Cardoso, mas também de idade, que pode significar, por exemplo, extensão cronológica. No caso. então, Idade do Bronze, quem sabe possa conotar algo como: III e II milênios aC.? E não é que havíamos explicitado tal conotação 
com que empregávamos a expressão já na própria resenha, por meio de um parênteses à mesma: Idade do Bronze (III e II milênios $a C$ ) (33). Novamente, o Prof. Cardoso silencia essa nossa explicitação na resenha, e quando reproduz em sua resposta 0 trecho da nossa resenha de que se vale para tecer aquele comentário denunciador, corta-o de forma a obliterar a referida explicitação. É sempre a mesma estratégia de leitura.

Mas também uma abordagem mais aprofundada e intelectual da categoria Idade do Bronze legitima o nosso emprego da expressão. Pois não é que Leonard Wooley (para citar como exemplo um autor que goza do reconhecimento de autoridade de parte do Prof. Cardoso) (34), assim também a emprega. É curioso não ter o Prof. Cardoso, então, denunciado que a nossa imaginada ignorância era também a de Leonard Wooley, já que certamente o Prof. Cardoso conhece sua obra. Mas o critério que para tal Autor distingue a Idade do Bronze do Calcolítico (35) não é o conhecimento do metal (se bronze ou cobre), mas o da metalurgia. A não ser que seja isso que o Prof. Cardoso esteja precisamente querendo nos ensinar com o seu precioso comentário: no Egito, na época referida, desconhecia-se a metalurgia (36). Mas se não for isso que ele quer dizer, então quer nos parecer que a ignorância não é nossa. Reluto em suspeitar que seja do Prof. Cardoso, sempre solícito e cuidadoso em demonstrar seu egrégio saber. Mas, então, será que o Prof. Cardoso desvirtuou o entendimento da nossa conotação daquela expressão, para assim forçar a denúncia de nossa ignorância?

Mas, quem está dominado, no seu pensar, pelos horizontes limitados da categoria nação, privilegia mesmo o espaço por ela recortado como referência do seu pensar. No interior desse espaço, percorre a temporalidade a fim de ir identificando os estágios tecnológicos. Constatando a não estrita contemporaneidade dos mesmos ao se considerarem os diversos "espaços-nações", adapta-se a cada um destes uma identificaçáo cronológico-tecnológica própria. E daí proliferam os Calcolíticos (o mesopotâmico, o egípcio), os Neolíticos (o da Europa Central, o da África setentrional), as Idades do Bronze (a da Anatólia, a da península itálica). e vai por aí afora. Muito bem, tal é a forma de pensar comandada pela categoria nação.

(33) - A página 176, último parágrafo.

(34) - Confira-se precisamente a obra desse Autor citada pelo Prof. Cardoso na sétima nota de rodapé de sua resposta.

(35) - A resposta do Prof. Cardoso sugere, embora ele não explicite cabalmente, estar ele operando tal deslocamento conceitual (confiram-se os nossos grifos à sua frase).

(36) - Não tivemos acesso à obra referida pelo Prof. Cardoso para allcorar - seu comentário, e assim precisar tal ponto. 
Revela outra preocupação e descortina outra largueza de visão, porém, quem pensa Idade do Bronze por aquela aparentemente despretenciosa conotação de extensão cronológica: III e II milênios $\mathrm{aC}$. Delimitando essa temporalidade, o interesse do conceito volta-se para o espaço constituido pelas relações de troca efetuadas no seu transcorrer. E a historicidade implicada por essas relações nesse espaço amplo que se busca apreender, ao invés de atender os reclamos classificatórios da trajetória histórica dos passos tecnológicos das nações separadas.

Mas é que essa forma de pensar comandada pela categoria nação, com a sua preocupação classificatória de adaptação cronológica ao espaço da nação, não é uma criação original do Prof. Cardoso. O seu livrinho, como um bom manual, simplesmente reproduz, conserva e consagra o que é típico da tradição destes. Aliás, já a própria eleição do objeto O Egito Antigo - marca a filiação do livrinho a essa tradição dos manuais de história que participam de coleções: situando-se no interior do cristalizado esquema europocêntrico de periodização instituidor da categoria Antiguidade, apresentam um mosaico histórico de entidades nacionais (Egito, Babilônia, Assíria, Fenícia, Pérsia, Grécia, Roma). A consistência de tais objetos não é de ordem teórico-epistemológica. E sim, como já o apontou Jean Chesneaux (37), por um lado, político-ideológica e, por outro, burocrático-institucional. Pelo viés político-ideológico, tais objetos afirmam a categoria nação como valor enraizado na História Universal, solidarizando-a aos demais valores constituintes do horizonte ideológico burguês. Pelo viés burocrático-institucional, tais objetos prestam-se a vários usos e serventias: canal de ascensão na carreira universitária, organizada en cátedras ou titulaturas; critério de distribuição dos financiamentos estatais de pesquisa; polo de aglutinação das "camarilhas universitárias" (38); campos de especialidades científicas que ensejam o exercício do discurso competente como instrumento de poder. E tambèm produto de consumo cultural da classe média na sociedade de massas. E aqui retorna a questão da inserção do livrinho na coleção Tudo é História, como o Prof. Cardoso insiste em sua resposta. Examinemos, então, a trajetória de sua argumentação.

(37) - Chesneaux, J., Hacemos Tabla Rasa del Pasada?, troducion de A. C. del Camino, Mexico, Siglo XXI, 1977. Temos consciência que este livro parece não gozar das boas graças do Prof. Cardoso, como ele deixa transparecer num dos seus manuais de metodologia (o abreviado). Tal pode parecer mais uma das nossas "im-pertinências", mas é que nesse livro o Autor trata precisamente de questões relevantes para a nossa reflexão: coleções de História Universal, escaninhos da carreira universitária, consumo de produtos culturais pela classe média, etc.

(38) - Exceção que abrimos ao nosso propósito de reservar as aspas para expressões retiradas do texto do Prof. Cardoso, propósito este que estoicamente mantivemos até aqui. Neste caso, elas referem-se à autoria de Chesneaux. 
Ele, de início, apela para a razão da "sensatez" e da "pertinência" implicadas por essa inserção. Entende que essa razão interdita-lhe "profundas intenções teóricas e interpretativas". Esclarecemos que tal interdição limitadora não foi por nós apontada em nossa resenha, devendo-se ela exclusivamente ao entendimento da coleção pelo Prof. Cardoso. A seguir, situa o valor do livrinho no horizonte do que ele "constata" como limitações, insuficiências e deficiências generalizadas do ensino de História Antiga no Brasil, tanto no âmbito institucional quanto no bibliográfico (39). Modestamente, portanto, dá a entender que o seu livrinho - obra que reage contra esse estado de coisas - dá início à redenção da História Antiga no Brasil. E finalmente, mais adiante na sua resposta, desvenda - Prof. Cardoso tesouros "interpretativos" que ele reserva para "honrar" outras publicações que não os livrinhos da coleção, ou para "honrar" outras plagas que não a "desinformada" terra brasileira. E iustifica essa poupança, alegando a "despretensão" do livrinho: um "texto introdutório destinado a principiantes". Assim, por exemplo, ele declara ter já firmado opções quanto à questão da periodização contra o esquema tradicional. Mas, preocupado em não "desconcertar" a cabeça da "maioria dos leitores", paga seu tributo àquele esquema. E, por este esquema, concerta o livrinho. E assim, em nome da "sensatez", o Prof. Cardoso atua intelectualmente segundo uma nítida dissociação: reflexões elevadas. complexas" e "profundas" ficam destinadas para uma elite acadêmica; divulgação de "informações atualizadas", nuançadas de "interpretações" (as não "profundas"), são concedidas aos leitores comuns.

Então, propósitos de divulgação e difusão de informação, precisa e atualizada. Missão propedêutica imbuida de cientificidade. Cruzada educadora pelas plagas indígenas ignaras. Realmente, Prof. Cardoso, nada melhor do que um manual para cumprir tais intenções. E o manual parece ser o zelo mais "recente" do Prof. Cardoso no campo intelectual: além do que resenhamos, mais outros dois livrinhos na mesma coleção, além dos manuais de metodologia, um alentado, outro abreviado. Então, Prof. Cardoso, noves fora, vossa resposta confirma plenamente a intenção da nossa resenha: situar o livrinho como manifestação da velha e tradicional modalidade dos manuais de história.

Assim, a contraposição de posicionamentos interpretativos por nós visada adquire seu sentido pleno. De um lado, temos o que se apresenta como inovador e superador do velho, mas que, pelo contrário, efetua a reprodução e consagração das formas típicas deste: o manual. Tal é o livrinho do Prof. Cardoso. Aparece travestido do novo, diria Marx.

(39) - A valiđade da afirmação, especialmente o seu viés generalizante, fica por conta da convivência pessoal do Prof. Cardoso com o ensino de História Antiga no Brasil. 
Vestimenta conceitual-interpretativa em costumes marxistas, seguindo a moda bibliográfica mais "recente". Todavia, essencialmente perpetua $o$ corpo do manual de inspiração positivista: metodologia da fragmentação e recorte, tanto na constituição do objeto, quanto no exame analítico deste; demonstração de saber e domínio bibliográfico; acúmulo de informacão à guisa de divulgação; e postulação de posse da "verdade" científica. E não são essas mesmas as faces da forma de pensar que transparecem igualmente na resposta com que nos brindou o Prof. Cardoso? De outro lado, temos a proposta interpretativa do curso por nós numerado na resenha. Situando a reflexão em horizontes mais amplos, enriquece a inteligibilidade dos mesmos com a abertura crítica pela qual constrói sua reflexão.

Tal era a reflexão que tencionávamos esclarecer. Percebo agora que, se não fui tomado pelo ofuscamento da hýbris ao compor minha resenha, neste esclarecimento ela se vingou exemplarmente determinando a extensão do mesmo. Fazemos votos de agora ter-nos feito entender, e que agora as coisas fiquem claras. E nada mais temos a esclarecer. Se, entretanto, tal esclarecimento for considerado ainda insuficiente, então, Prof. Cardoso, tendes de vossa parte todas as condiçōes, requisitos e posicionamentos de superioridade para encarar a nossa resenha daquela altura e distância com que o nobre Taltíbio condescendentemente irrelevou a insana profecia de Cassandra nas Troianas de Eurípedes: "serão palavras vãs, o vento as levará". Mas o trágico comporta ironia, e as palavras de Cassandra não foram vãs, nem tampouco o vento as levou. Os insígnes heróis gregos, vencedores de Tróia, que o digam.

De nossa parte, uma vez encerrado este esclarecimento, destinamos à vossa resposta a mesma sorte que Hamlet, calando a inquirição de Rosencrantz, declarou ter dado ao corpo de Polônio: "Associei-o ao pó, de que é parente". 